\title{
UPAYA MENINGKATKAN HASIL BELAJAR BERHITUNG PENJUMLAHAN DAN PENGURANGAN PESERTA DIDIK MELALUI METODE PEMBERIAN TUGAS DI KELAS 1 SD NEGERI SEMPUR KIDUL SEMESTER 2 TAHUN PELAJARAN 2018/2019
}

\author{
SRI RUPIYANTI \\ SDN Sempur Kidul Kota Bogor, Jawa Barat \\ rupiyantisri@gmail.com
}

\begin{abstract}
ABSTRAK
Tujuan penelitian ini adalah untuk meningkatkan hasil belajar peserta didik pada mata pelajaran matematika tentang penjumlahan dan pengurangan melalui metode pemberian tugas. Metode penelitian yang digunakan adalah metode eksperimen dengan subjek penelitian adalah peserta didik kelas 1 SDN Sempur Kidul Bogor yang terdiri dari 28 peserta didik. Pelaksanaan penelitian tindakan kelas ini di lakukan pada semester 2 tahun pelajaran 2018 - 2019. Proses penelitian tindakan kelas ini dilakukan tiga siklus, yaitu siklus 1, siklus 2, dan siklus 3 setiap siklus terdiri dari empat tindakan utama yaitu perencanaan, pelaksanaan tindakan, observasi, dan refleksi. Akhir dari setiap siklus dilaksanakan tes menggunakan instrumen soal. Kemudian hasil yang diperoleh pada pertemuan pertama , kedua dan pertemuan ketiga dirata - ratakan untuk menjadi hasil akhir dari setiap siklus. Jika dilihat kenaikan hasil belajar dari siklus $1 \mathrm{ke}$ siklus 2, terjadi kenaikan persentase ketuntasan sebesar 46,42 \% yaitu ketuntasan belajar pada siklus 1 sebesar 14,29\% menjadi 60,71\%, sedangkan dari siklus 2 ke siklus 3,terjadi peningkatan ketuntasan belajar sebesar 28,59 \% yaitu dari 60,71\% menjadi 89,3\% rata-rata 84. Peserta didik yang memperoleh nilai mencapai KKM dari siklus 1 sebanyak 4 orang atau sebesar 14,29\% menjadi 25 orang atau sebesar 89,3\% yang berarti kenaikanya sebesar 28,59 $\%$. Peserta didik yang memperoleh nilai belum mencapai KKM pada siklus 3 sebanyak 3 orang atau sebesar 10,7 \%, Apabila dibandingkan antara hasil tes pada kondisi awal dengan hasil tes pada siklus II, akan terlihat perubahan yang lebih signifikan yaitu kenaikan rata-rata nilai dari 60 menjadi 84, berarti kenaikan sebesar 24. Peserta didik yang memperoleh nilai mencapai KKM dari 4 orang atau sebesar 14,29\% menjadi 25 orang atau sebesar 89,3\%, berarti kenaikan sebanyak 21 orang atau sebesar $75,01 \%$. Sedangkan peserta didik yang memperoleh nilai belum mencapai KKM yang semula sebanyak 24 orang atau sebesar 85,71\% berkurang menjadi sebanyak 3 orang atau sebesar $10,7 \%$, berarti terjadi penurunan sebanyak 11 orang.

Kata Kunci : Hasil Belajar Peserta Didik, Mata Pelajaran Matematika Materi

Pemjumlahan dan pengurangan, Metode Pemberian Tugas.
\end{abstract}

\section{PENDAHULUAN}

Dalam dunia pendidikan, matematika merupakan salah satu pelajaran yang menduduki peranan penting. Hal ini karena matematika mempunyai karakteristik dalam melatih seseorang atau peserta didik, antara lain digunakan untuk berpikir secara logis, kritis, sistematis, tekun, dan kreatif (Nuckman : 2009). Selain itu, peningkatan mutu pendidikan metematika sangat penting karena pendidikan matematika merupakan pondasi bagi perkembangan Ilmu Pengetahuan dan Teknologi (IPTEK) yang sangat berperan pula dalam peningkatan mutu sumber daya manusia. Sehingga wajar kiranya jika pendidikan matematika harus diberikan atau dipelajari mulai sejak sekolah dasar, dan terus berlanjut di tingkat sekolah menengah pertama, kemudian di tingkat sekolah menengah atas dan di perguruan tinggi (Hamalik : 2003). Karena dalam pelaksanaan pendidikan khususnya bidang studi matematika ini berisi materi-materi yang bersifat teoritis. maka peserta didik yang mengikuti bidang studi ini dituntut memiliki sejumlah kemampuan dalam memahami semua materi dan dalam menyelesaikan soal-soalnya.

Rasa takut yang berlebihan dan menganggap matematika sebagai pelajaran yang sangat sulit menjadi kendala tersendiri dalam pembelajaran matematika. Selain itu ada yang menganggap 
bahwa pelajaran matematika sebagai pelajaran yang menakutkan, sehingga rasa malas sering kali menghinggapi perasaan peserta didik mulai dari tingkat dasar sampai tingkat menengah untuk belajar matematika, bahkan membuat peserta didik menjadi asing dan cenderung memusuhi pembelajaran matematika. Sikap dan persepsi negatif tersebut cenderung kurang dipahami oleh peserta didik sehingga membuat hasil belajar matematika menjadi lebih buruk atau hasilnya sangat rendah (Amien : 2008).

Hasil belajar peserta didik kelas 1 SDN Sempur Kidul Kota Bogor untuk mata pelajaran berhitung dalam kemampuan penjumlahan dan pengurangan sangat rendah, terbukti setiap kali diadakan ulangan, hasil rata-rata yang diperoleh tidak memuaskan. Hasil nilai yang diperoleh sebanyak 24 orang dari 28 peserta didik belum mencapai ketuntasan yaitu sebesar 85,71\% dan hanya sebesar 14,29\% yang mencapai keteuntasan. Kondisi awal peserta didik nilai berhitung sangat rendah, melalui penelaahan yang mendalam penulis mencari sebab-sebabnya, salah satunya adalah belum dimanfaatkannya metode sebagai alat bantu yang bisa merangsang peserta didik dalam mencerna proses pembelajaran yang dalam hal ini pemberian tugas. Kualitas dan kuantitas belajar peserta didik di dalam proses belajar mengajar tergantung banyak faktor antara lain peserta didik dalam kelas, peserta didik belum menguasai materi pelajaran, peserta didik lambat dalam memahami materi yang diajarkan; bahan-bahan pelajaran, perlengkapan belajar, lingkungan sekolah, kondisi umum dan suasana dalam proses belajar mengajar serta teknik penyampaian pelajaran yang menyangkut teknik mengajar di kelas akan lebih hidup dan menarik juga menyenangkan, daya tangkap peserta didik akan mudah apabila guru mampu memilih dan menggunakan banyak latihan. Dimanfaatkannya latihan sebagai sarana pembelajaran untuk memperjelas dan mempermudah memahami dari konsep yang abstrak akan menjadi bertambah jelas dan pada akhirnya nanti peserta didik mendapat hasil belajar yang meningkat. Harapan dari penulis melalui latihan dapat meningkatkan hasil belajar berhitung.

Setelah mengadakan wawancara dan tes awal yang digunakan sebagai nilai siklus 1, maka salah satu penyebab nilai anak rendah terutama pada materi penjumlahan dan pengurangan adalah pendidik ketika menerangkan selalu dengan ceramah yang diakhiri dengan penugasan saja. Peserta didik mengaku jenuh dengan ceramah saja. Untuk menghadapi permasalahan diatas penulis mencoba memberi motivasi dan inovasi yang salah satunya mengganti metode pembelajaran. Metode pembelajaran yang diganti adalah metode yang bisa membekali peserta didik dengan keterampilan yang disarankan dalam implementasi Kurikulum 2013 yaitu salah satunya adalah metode pemberian tugas.

\section{METODE PENELITIAN}

Pelaksanaan penelitian dijadwalkan dengan limit waktu 6 bulan terhitung dimulai bulan Januari sampai dengan Juni 2019.Penelitian berlokasi di SD Negeri Sempur Kidul Kota Bogor. Pemilihan SD Negeri Sempur Kidul Kota Bogor sebagai tempat penelitian adalah karena peneliti sebagai guru guru kelas 1 di sekolah tersebut, hal ini dapat memudahkan dalam mencari data, peluang waktu yang luas, memudahkan pada peserta didik agar keaktifan tetap terjaga dan subjek penelitian sesuai dengan profesi peneliti. Kelas yang menjadi subjek penelitian adalah peserta didik kelas 1 SD Negeri Sempur Kidul Kota Bogor Tahun Pelajaran 2018 - 2019 berjumlah 28 orang terdiri atas 17 laki-laki dan 11 perempuan .Penelitian Tindakan Kelas (PTK) bersifat siklus atau berdaur yang terdiri dari empat langkah, yaitu : (1). Penetapan fokus masalah (2). Perencanaan Tindakan (3). Pelaksanaan Tindakan dan Observasi (4). Analisis dan Refleksi. Berdasarkan teknik pengumpulan data di atas, instrumen yang digunakan dalam penelitian adalah : (1). Instrumen tes menggunakan butir soal isian (instrumen soal terlampir), (2) Instrumen observasi menggunakan daftar ceklis (lembar observasi terlampir) (3) Dokumentasi menggunakan foto-foto yang diambil ketika peserta didik terlibat dalam proses pembelajaran melalui metode eksperimen sebagai bukti penelitian yang dilakukan (foto-foto terlampir). (4) Instrumen kepustakaan menggunakan buku-buku sebagai referensi. Data yang diperoleh dari hasil observasi dan tes selama proses belajar mengajar, selanjutnya dianalisis 
dengan menggunakan statistik deskriptif. Menghitung Ketuntasan Klasikal. Penelitian ini berhasil adalah jika hasil belajar peserta didik yang dikomulatifkan dengan nilai adalah jika minimal $80 \%$ peserta didik nilai rata-ratanya 75 atau $80 \%$ peserta didik mencapai nilai Kriteria Ketuntasan Minimal (KKM).

\section{HASIL DAN PEMBAHASAN}

Pengamatan sintaks metode pemberian tugas dilakukan oleh 1 observer. Observer melakukan pengamatan pada sintaks pemberian tugas yaitu (1) menampilkan permasalahan, (2) menjelaskan permasalahan dengan mendorong siswa untuk merumuskan permasalahan, (3) membimbing peserta didik menyusun hipótesis, (4) merumuskan kesimpulan atau penjelasan atas penyelesaian dari permasalahan yang sudah dirumuskan, (5) guru membimbing peserta didik untuk menyusun kesimpulan. Hasil pengamatan menunjukan keterlaksaan sintaks setiap siklus sebagai berikut:

Berdasarkan data siklus I diperoleh keterangan bahwa dari 28 peserta didik ada 4 peserta didik yang mendapat nilai di atas Kriteria Ketuntasan Minimal (KKM) yaitu 75 dan dapat dikatakan bahwa peserta didik tersebut sudah mencapai ketuntasan belajar, sedangkan peserta didik yang mendapat nilai di bawah KKM ada 24 peserta didik dan ini berarti peserta didik tersebut dikatakan belum tuntas belajar. Nilai rata-rata peserta didik pada pra siklus adalah 60 .

\section{Ketuntasan Belajar Matematika}

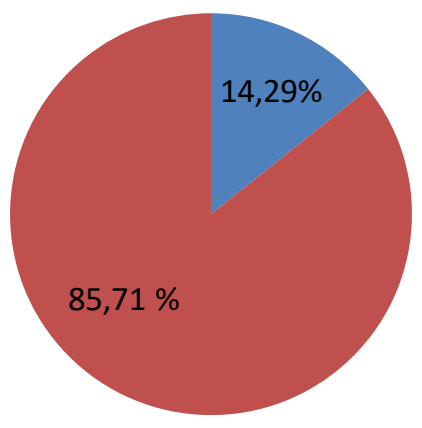

Tuntas

- Tidak Tuntas

\section{Gambar 1. Diagram Ketuntasan Hasil Belajar Siklus1}

Berdasarkan data siklus I diperoleh keterangan bahwa dari 28 peserta didik ada 4 siswa atau 14,29 \% yang mendapat nilai di atas Kriteria Ketuntasan Minimal (KKM) yaitu 75 dan dapat dikatakan bahwa peserta didik tersebut sudah mencapai ketuntasan belajar, sedangkan peserta didik yang mendapat nilai di bawah KKM ada 24 peserta didik atau 85,71\% .Ini berarti peserta didik tersebut dikatakan belum tuntas belajar. Nilai rata-rata peserta didik pada siklus I adalah 60 . 


\section{Ketuntasan Belajar Matematika}

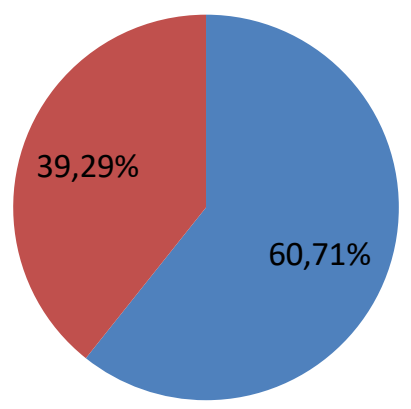

Tuntas

- Tidak Tuntas

Gambar 2. Diagram Ketuntasan Hasil Belajar Siklus II

Berdasarkan data siklus II diperoleh keterangan bahwa dari 28 peserta didik ada 15 peserta didik atau 60,71 \% yang mendapat nilai di atas Kriteria Ketuntasan Minimal (KKM) sehingga dapat dikatakan bahwa peserta didik tersebut sudah mencapai ketuntasan belajar, sedangkan peserta didik yang mendapat nilai di bawah KKM ada 11 peserta didik atau 39,29 $\%$. Ini berarti peserta didik tersebut dikatakan belum tuntas belajar.

\section{Ketuntasan Belajar Matematika}

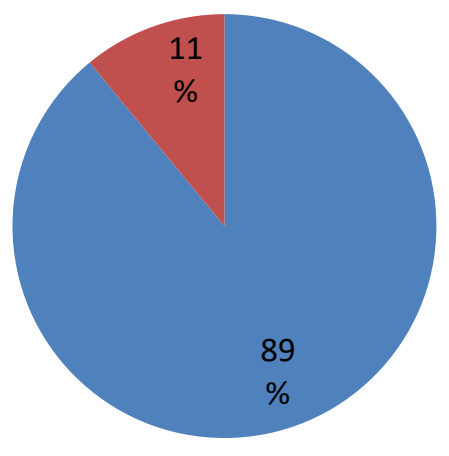

- Tuntas

Tidak Tuntas

Gambar 3. Grafik Ketuntasan hasil belajar siklus III

Berdasarkan hasil observasi terhadap keaktifan peserta didik, maka dapat diperoleh keterangan bahwa selama proses pembelajaran aktivitas peserta didik sudah mengalami kemajuan kearah yang lebih baik. Hal ini dibuktikan dengan keaktifan peserta didik selama proses pembelajaran, kesadaran bekerja sama dan meneliti sudah tumbuh dalam diri masing-masing peserta didik dengan teman-teman nya baik dalam satu kelompok maupun kelompok lain.

Pada pembelajaran siklus 1 menunjukkan bahwa proses pembelajaran menggunakan metode ceramah yang dilakukan oleh guru masih belum maksimal seperti yang diharapkan peneliti dalam pelaksanaannya. Hal ini terbukti masih ada peserta didik yang kurang aktif dan kurang bersemangat selama proses pembelajaran. Selain itu proses pembelajaran ini pada awalnya memakan waktu, tapi pada pertemuan selanjutnya peserta didik lebih terbiasa dan semakin diberdayakan dalam belajar. 
Pada siklus II peserta didik semakin terbiasa dengan pembelajaran pemberian tugas. Beberapa masalah yang dialami pada siklus sebelumnya, seperti masih adanya peserta didik yang tidak aktif selama proses pembelajaran dapat teratasi dengan mengorganisasikan peserta didik ke dalam kelompok-kelompok belajar. Peserta didik yang mempunyai kemampuan akademik baik akan bertindak sebagai tutor sebaya dan dalam pelaksanaannya sangat bermanfaat bagi peserta didik itu sendiri. Dengan menyampaikan pengetahuannya pada peserta didik lain ia akan mengulang kembali apa yang telah diketahuinya. Demikian juga dengan peserta didik yang tergolong memiliki kemampuan akademik rendah akan lebih mudah belajar dari teman karena tidak segan untuk bertanya dan menggunakan bahasa yang lebih mudah dipahaminya.

Penerapan pemberian tugas pada peserta didik kelas 1 sangat berpengaruh pada hasil belajar kognitif yang dicapai peserta didik. Hasil tes menunjukkan bahwa rata-rata kelas sebelum menerapkan pemberian tugas adalah 60 menjadi 74 pada siklus II dan meningkat menjadi 84 pada siklus III. Dengan demikian penerapan pemberian tugas dalam penelitian ini menunjukkan perubahan positif pada hasil belajar peserta didik. Hasil belajar dapat meningkat karena adanya saling membelajarkan antar peserta didik melalui kerja kelompok.

Pelaksanaan pemberian tugas juga dapat meningkatkan aktivitas guru dan peserta didik yaitu memberi ruang untuk lebih aktif, karena melibatkan lebih banyak indera guna menerima informasi yang dapat diterima dan dipahami. Peserta didik belajar tidak hanya asal mengerjakan soal tetapi peserta didik terlibat terutama dalam proses mentalnya untuk menemukan beberapa konsep dan prinsip .
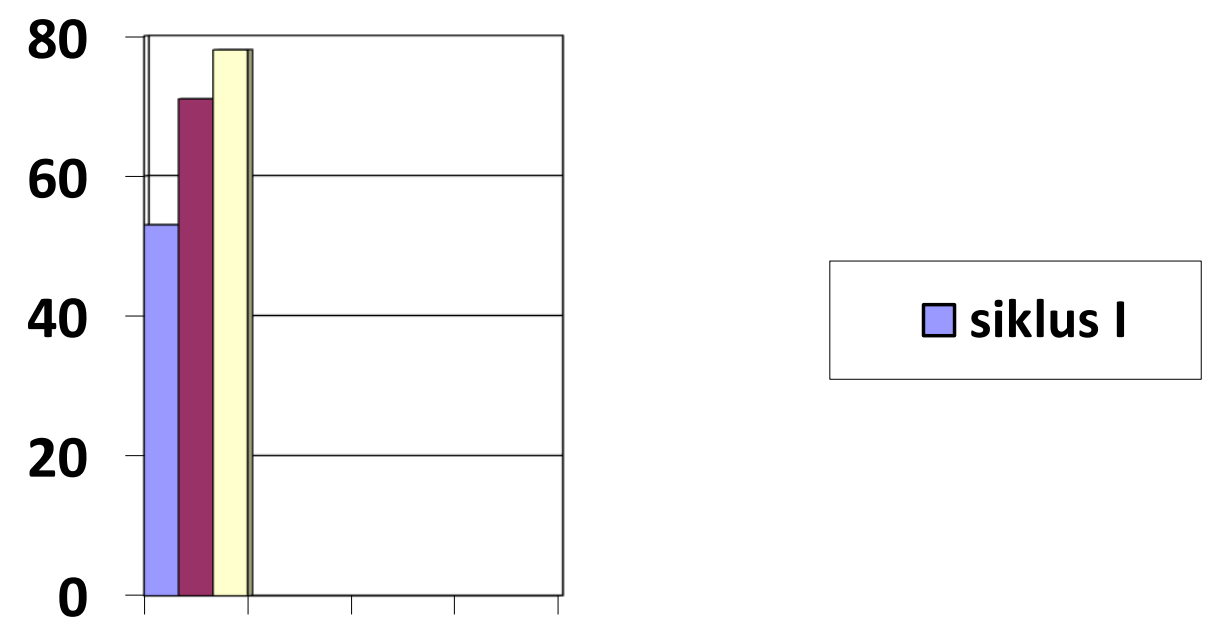

Bambar 4. Grafik rata-rata nilai hasil belajar peserta didik dari pra siklus - siklus II mata pelajaran matematika

Keaktifan berperan penting dalam pencapaian tujuan dan hasil belajar yang memadai dalam proses belajar mengajar. Sesuai dengan pendapat Nasution (2010) keaktifan belajar merupakan asas yang terpenting dalam proses belajar mengajar. Keaktifan belajar dibagi menjadi dua, yaitu keaktifan jasmani dan rohani. Kedua-duanya harus berhubungan. Dapat dikatakan begitu, karena belajar itu sendiri merupakan suatu keaktifan, tanpa keaktifan tak mungkin seorang mengalami belajar. Bukan hanya fisiknya yang melakukan keaktifan, akan tetapi jiwanya juga harus ikut melaksanakan keaktifan belajar. Kedua keaktifan tersebut tidak bisa berdiri sendiri. Pembelajaran modern menitikberatkan pada keaktifan atau keikutsertaan peserta didik. Agar pembelajaran berhasil keaktifan belajar harus didorong oleh macam-macam kebutuhan. Peserta didik adalah organisme hidup yang memiliki macam-macam kebutuhan untuk mendorongnya berkembang. Hal inilah yang mendorong guru juga untuk menjadi fasilitator sehingga meningkatkan keaktifan belajar siswa. Nasution (2010) menegaskan bahwa dalam pendidikan anak-anak sendirilah yang harus aktif. Artinya anak yang berbuat. Keaktifan 
siswadijadikan indikator dalam pendidikan. Siswa yang aktif dinamakan sudah mendapatkanpendidikan. Dikatakan demikian karena dari berbuatlah anak mendapat pengalaman belajar. Keaktifan belajar siswa yang relevan dalam pembelajaranlah yang dapat mengubah tingkah laku peserta didik sesuai dengan tujuan pembelajaran. Tanpa adanya keaktifan belajar siswa tersebut, perubahan tingkah laku tidak terwujud, sehingga yang dinamakan belajar pun tidak pernah terjadi.

Berdasarkan hasil penelitian di atas diketahui bahwa metode pemberian tugas berhasil meningkatkan keaktifan dan hasil belajar siswa dari pra siklus sampai siklus III dikarenakan dalam menerapkannya sesuai dengan sintaknya dan guru berhasil memancing siswa untuk terlibat aktif dalam pembelajaran dengan menemukan dan mengorganisasikan konsep materi sendiri sehingga siswa dapat memahami materi pelajaran secara leluasa. Sesuai dengan pendapat Hanifah dan Wasitohadi (2017:95) bahwa pemberian tugas ialah rangkaian kegiatan pembelajaran yang melibatkan siswa untuk belajar aktif menemukan pengetahuan sendiri. Pendapat itu juga sejalan dengan pendapat Siswanti dan Wahyudi (2015:27) bahwa pemberian tugas merupakan proses pembelajaran di mana siswa tidak disajikan pelajaran dalam bentuk finalnya, tetapi diharapkan siswa mengorganisasi sendiri dan model ini lebih menekankan pada penemuan konsep atau prinsip yang sebelumnya tidak diketahui. Sehingga belajar dengan menggunakan model ini siswa akan penasaran dan lebih tertarik mengikuti pembelajaran sehingga dapat berpartisipasi aktif dalam kegiatan belajar dengan melakukan segala sesuatunya sendiri untuk dapat menemukan dan mengorganisasi materi sendiri dengan suatu percobaan atau pengamatan sehingga siswa akan lebih memahami materi secara leluasa

Hasil penelitian ini mendukung penelitian sebelumnya yang pernah dilakukan oleh Rita Y (2017), Istikomah, dkk (2018) dan Gina, dkk (2016) yang telah membuktikan meningkatnya keaktifan dan hasil belajar siswa dengan menerapkan model pemberian tugas. Hasil penelitian Rita Y (2017) diperoleh keaktifan siswa pada siklus I mencapai 50\%, siklus II $67 \%$ dan mengalami peningkatan pada siklus III 92\%. Sedangkan penelitian Istikomah N, dkk (2018) menghasilkan keaktifan siswa pada siklus I mencapai $86 \%$ dan pada siklus II 95\%. Kemudian hasil belajar siswa dapat dilihat dari hasil penelitian Gina R, dkk (2016) yang menghasilkan, pada siklus I hasil belajar siswa mencapai presentase ketuntasan sebesar 26,92\%, siklus II mencapai presentase ketuntasan sebesar 65,38\%, pada siklus III mencapai 88,46\%. Berdasarkan penelitian yang telah dilakukan oleh beberapa peneliti menunjukkan bahwa model pemberian tugas dapat meningkatkan keaktifan dan hasil belajar siswa.

Berdasarkan uraian di atas dapat disimpulkan bahwa keaktifan belajar merupakan segenap rangkaian kegiatan atau perbuatan yang dilakukan seseorang secara sadar baik jasmani maupun rohani selama proses pembelajaran berlangsung yang mengakibatkan perubahan dalam dirinya sehingga menciptakan lingkungan belajar yang kondusif. Keaktifan belajar berkaitan erat dengan fisik dan jiwa. Keaktifan belajar fisik merupakan keaktifan yang dapat dilihat oleh orang lain.

\section{KESIMPULAN}

Hasil belajar berhitung pada materi penjumlahan dan pengurangan yang diajar dengan metode pemberian tugas berada pada kategori sangat baik, dengan nilai rata-rata pada siklus I sebesar 60 ; pada siklus ke II sebesar 74; sedangkan pada siklus III sebesar 84. Kondisi ini menunjukkan bahwa nilai rata-rata mengalami kenaikan sebesar 14 dari siklus I ke siklus II, $18,92 \%$ dari Siklus II ke siklus III sebanyak 10 , berarti $11,10 \%$ mencapai nilai KKM.

Terdapat perbedaan hasil belajar peserta didik pada mata pelajaran matematika dengan materi berhitung sebelum diajarkan menggunakan metode pemberian tugas dengan setelah diajarkan menggunakan metode pemberian tugas . Hal ini didukung oleh rata-rata hasil belajar peserta didik yang mengalami perubahan secara signifikan. Berdasarkan kesimpulan di atas, maka beberapa saran terkait yang dapat penulis sampaikan pada penelitian ini adalah :

1. Mengingat masih banyak hal yang harus diperbaiki dalam meningkatkan hasil belajar berhitung, maka perlu diperhatikan metode pemberian tugas yang disesuaikan dengan 
motivasi belajar peserta didik sehingga dapat meningkatkan hasil belajar peserta didik pada mata pelajaran matematika.

2. Metode pemberian tugas merupakan suatu komponen yang dapat mempengaruhi hasil belajar. Oleh karena itu, sebaiknya guru dapat memetakan tingkat motivasi belajar untuk selanjutnya disesuaikan dengan metode pemberian tugas.

3. Proses pembelajaran yang dilaksanakan di sekolah seharusnya dapat membangkitkan kemandirian belajar peserta didik, hal ini dapat dilakukan dengan memberikan kepercayaan kepada peserta didik untuk berhasil memperoleh prestasi dalam belajar.

4. Kepala sekolah dan pengawas dapat meningkatkan kemampuan profesional guru dalam mengajar dengan berbagai pendekatan dan metode pembelajaran melalui supervisi klinis untuk kepentingan guru secara individual atau institusi.

\section{DAFTAR PUSTAKA}

Depdiknas. Undang-undang Republik Indonesia No. 20 Tahun 2003 tentang Sistem Pendidikan Nasional. Bandung : Fokus Media.

Priyatno, Duwi. 2009. Belajar Olah Data SPSS. Yogjakarta : Andi Offset

Nukman, Ilhamuddin. 2009. Mind Revolution. Jogjakarta: Diva Press.

Muchith, M. Saekhan. 2008. Pembelajaran Kontekstual. Semarang: Rasail Media Group.

Amien, Mappadjanti .2008. Kemandirian Lokal. Jakarta : Gramedia.

Hamalik, Oemar . 2003. Proses Belajar Mengajar. Jakarta : Bumi Aksara.

Ridwan. 2005. Belajar mudah Penelitian untuk Guru- karyawan dan Peneliti Pemula. Bandung: Alfabeta.

Nasoetion, S. 2002. Berbagai Pendekatan dalam Proses Belajar dan Mengajar. Jakarta : Bumi Aksara.

Sudjana 2002. Dasar-dasar Proses Belajar Mengajar. Bandung: Sinar Baru Algesindo.

Sugiyono 2006. Metode Penelitian Pendidikan. Bandung : Alfabeta. 